\title{
Transparency of Public and Local Finances: Foreign Experience ${ }^{i}$
}

\author{
INNA O. SHKOLNYK ${ }^{i i}$, NATALIIA G. VyHOVSKA ${ }^{i i i}$, \\ YuLIIA S. HaVRYSH ${ }^{i v}$, ANDRII O. IVANCHENKo ${ }^{v}$
}

\begin{abstract}
In modern conditions, the role of transparency of both public and local finances is growing significantly, which is a tool to increase the efficiency of financial resources, which confirms the analysis of Ukrainian and foreign studies. In Ukraine, the level of transparency is improving every year and as of 2019 is assessed by international organizations as the minimum allowable. At the same time, the level of transparency of local budgets differs significantly in different regions. To improve the situation and implement best practices in the field of transparency of public finances at both the state and local levels, it is important to analyze the foreign experience of those countries that are leaders in ratings of transparency of public authorities and transparency of the budget process. The paper analyzes the experience of the Office of the Public Accountant of Texas (USA), the Treasury of New Zealand and the Treasury of the Republic of South Africa, which according to the open budget rating provided by the International Budget Partnership are among the 10 most transparent countries. Analysis of the content of the information portal of the Texas Public Accounts Controller Office showed a separate section "Transparency" with a detailed presentation of information in terms of key blocks of revenues and expenditures, state budget and finances, information on the formation and use of funds in all localities, information on budget deficit as well as information on transparency at the level of individual settlements, school districts, etc. A comparative analysis with the state of transparency of Ukrainian government agencies responsible for the development and implementation of financial policy and identifies weaknesses and strengths in terms of their transparency. It is established that the openness of the process of using public finances in Ukraine is gradually increasing, while the positions in the world transparency rating are also improving. However, the conceptual difference between building sites in the countries analyzed is that they report to taxpayers in a form that is accessible to them, rather than simply covering available information without comment or explanation.
\end{abstract}

Keywords: open budget, participation, public finances, rating, fiscal policy.

Introduction. The current state of public finances plays an important role in ensuring efficient economic processes both at the national level and at the local level. The importance of public finances has grown significantly in a pandemic, when state and local budgets become the source of funding for priority activities related to health care financing and other

${ }^{i}$ This work was supported by the Ministry of Education and Science of Ukraine (research topic № 0118 U003585 "Formation of a system for ensuring transparency of public finances as a prerequisite for combating corruption”)

${ }^{i i}$ Inna O. Shkolnyk, Dr. (Economics), Professor, Head of Department of Finance, Banking and Insurance, Sumy State University;

iii Nataliia G. Vyhovska, Dr. (Economics), Professor, Head of Department of Finance and Credit, State University "Zhytomyr Polytechnic";

${ }^{i v}$ Yuliia S. Havrysh, Graduate Student, Education and Research Institute for Business Technologies «UAB», Sumy State University;

Andrii O. Ivanchenko, Graduate Student, Education and Research Institute for Business Technologies «UAB», Sumy State University.

(C) I. O. Shkolnyk, N. G. Vyhovska, Yu. S. Havrysh, A. O. Ivanchenko, 2020

https://doi.org/10.21272/mer.2020.89.02 
social functions, as well as business support in a limited and slow economic activities. In this situation, the role of transparency in terms of both the formation and use of public finances increases significantly, because the more transparent the movement of financial resources at both national and local levels, the greater the degree of public confidence in public authorities and especially local authorities, as well as the lower risk of corruption. The importance of transparency in fiscal and budgetary policy is emphasized by international financial institutions, which in recent years have been monitoring transparency in the field of public administration, including in the field of public finance around the world.

It should be noted that if at the state level the issue of transparency of public finances is given serious attention both by the Ministry of Finance of Ukraine, the State Treasury Service, which develops and implements financial policy, and by the National Bank of Ukraine in the development and implementation of monetary policy. At the local level, the problem of ensuring the transparency of the formation and use of local budgets remains quite significant and requires a separate study.

To improve the situation regarding the transparency of local finances, it is useful to study foreign experience in this area. Particular attention should be paid to the state of local finances of those countries that show a high level of transparency in world rankings.

Analysis of recent research and publications. Problems of ensuring transparency in the field of public finance are in the center of attention of both foreign and domestic scholars. Moreover, they are relevant for both highly developed countries and developing countries, including Ukraine, and if for countries with a high level of economic development such studies have been conducted for a long time, in Ukraine this issue has become quite relevant relatively recently.

De Simone E., Bonasia M., Gaeta G.L., Sicatiello L. [10] investigated whether fiscal transparency, measured on the basis of the open budget index, affects the level of expenditures budget based on panel data from 82 countries for the period 2008-2015 and found that the level of transparency is directly related to the level of democracy in the country and at the same time in countries with established democratic values there is a higher level of transparency and it correlates with higher budget spending efficiency, while in countries with low level of democracy transparency has no effect on efficiency. Thus, the authors note that transparency can be a powerful tool in countries where politicians have a high degree of responsibility for their actions, and vice versa. De Renzio P. and Venus J. [9] conducted the systematization of research on the state of fiscal transparency and participation in the formation of the state budget for the period from 1991 to 2015 on the example of 38 studies. They found that increasing transparency and participation lead to better budgeting. The study of local finances was conducted by Erđavek N., Jakšić S., Maskić V. [11] on the example of Croatia using panel data and regression analysis, resulting in significant differences in different regions of both economic and political origin.

Zepich R., Dapp M., Krchmar H. [23] study the role of participatory budgeting in ensuring the transparency of the budget process on the example of different regions of Germany, they note that public participation in the budget process is important to ensure transparency of government.

Rios A., Guillaume M., Benito B., Bastida F. analyzed the impact of budget transparency on the 100 largest municipalities in Spain [19] and found that the level of transparency affects the deviation of forecasts in budget revenues, and it is directly related to the phases of election cycle, namely, found that in the year of elections, politicians usually overestimate the expenditure component. 


\section{І. О. Школьник, Н. Г. Виговська, Ю. С. Гавриш, А. О. Іванченко}

Транспарентність державних та місцевих фінансів: зарубіжний досвід

It is possible to achieve an increase in the level of transparency of government activities through the use of modern information technologies. Thus, M. Hartog and K. Bakker [13] on the example of six municipalities of the Netherlands determine the important role of digitalization in ensuring the transparency of the budget process and the formation of an open government. Birskite L. [8] studied the state of use of new technologies by municipalities in Lithuania for timely and comprehensive disclosure of information on the budget process and determined transparency indices for each municipality. In 2019 Ganapati S., Sid G.P., Reddick S.G. [12] conducted a study on the state of fiscal transparency in some US states that implement open data portals and found that the main factors of effective public finances at the state level are adoption of transparency legislation, adaptation to the digital environment, and political response by state governments to public finances.

With regard to Ukraine, it can be noted that the study of transparency has become widespread in the context of the actions of public authorities and local governments. Among such researches it is necessary to allocate works of Tereshchuk G. [6; 7], which studied the peculiarities of the implementation of the transparency principle in the activities of local governments and argued that transparency is one of the main factors in increasing the economic and social potential of territorial communities. As for studies of transparency in the field of public finance, they mainly focus on the problems of ensuring it at the national level, and usually relate to ensuring transparency in the framework of fiscal or budgetary policy. A study conducted by Vinnichenko N. [2] is among the works in this direction which proposed several new approaches to ensure the transparency of budget management, improved the methodology for determining priority areas for its provision and evaluation at the local level. In the work of Bak N. [1], the complex approach at the mechanism formation of qualitative disclosure in the budgetary information, and also wider access of the public to the process of formation of profitable and expense parts at the national level is investigated. Gasanov S. [3] conducted a comparative analysis of the compliance of certain provisions of the Budget Code of Ukraine with the basic principles of the IMF Fiscal Transparency Code of 2014 [14]. It should be noted that in 2019 [15] this document was revised and supplemented by a number of new positions related to revenue management. Regarding the study of the transparency of local finances, this area is not widely developed in Ukraine. Among the scholars dealing with this issue, it is appropriate to single out Liuta O. and Mershchii B. [16], who proposed a new approach to assessing the relationship between the state of socio-economic development of the region and the level of transparency of local authorities. As a result, the authors concluded that to strengthen transparency at the regional level it is necessary to improve the quality of information disclosure on the budget process, use Internet channels, social networks for information, create convenient forms of public involvement in the budget process. In the work of Nakonechna Yu. and Demydenko, L. [5] the peculiarities of using the method of calculating the budget openness index used by the international organization "International Budget Partnership” are analyzed and the main directions of improving the transparency of public finances in Ukraine are identified.

Given the fact that Ukraine crossed the mark of minimally sufficient openness of the budget process in the international rating of budget transparency only in 2019, it is now relevant to study foreign experience in the field of transparency. 21 Internet portals from 4 regions of Ukraine were evaluated in previous studies conducted by the authors of this study on the state of transparency of local finances in Ukraine [20], which were selected by geographical location - northern, southern, western, and eastern regions and Kyiv. As a result, 
there are significant differences in approaches to information disclosure on the state of local finances.

The purpose of the article is to study foreign experience in ensuring transparency in the field of public finances at the local level to identify best practices for their further implementation in local finances of Ukraine.

Research results. To identify ways to improve the level of transparency of public authorities, it is necessary to conduct research on the best information portals of other countries. The Texas Public Account Controller's Office in the United States is one of them.

The Texas Public Accounts Comptroller's Office has been operating in Texas since 1835 [21]. In fact, the Comptroller is the chief administrator of the state's financial resources, performs fiscal functions, i.e. collects taxes, administers public accounts, acts as chief analyst and manager of the state treasury, in addition, he is the organizer of many socio-economic programs. That is, it is a separate financial and economic body that provides all the economic management of the state and communication with the federal budget. It is difficult to draw an analogy with Ukraine, because the state system is radically different compared to the United States, which forms a completely different structure of state and local government. However, comparing the state of Texas and Ukraine separately, the Texas Comptroller's Office combines the functions of the State Fiscal Service and the State Treasury of Ukraine.

The control service serves almost every citizen in the state. As Chief Tax Officer, Accountant, Revenue Estimator, Treasurer, and Purchasing Manager in Texas, the agency is responsible for issuing checks and accounting.

As CFO, the controller's office collects taxes and fees due to the state and the state. State legislatures base their forecasts on the Comptroller's Office of Texas Economic Policy. Local officials and businesses contact the Agency for Economic Development and Data Analysis. The controller's office monitors compliance with tax laws and the effective, targeted and appropriate use of taxpayers' funds.

As a state cashier, the Comptroller's Office receives, distributes, calculates, protects, registers, manages, and notifies government funds. In addition, the Texas Comptroller heads the Treasury, which invests, manages and controls assets worth more than $\$ 50$ billion.

The controller's office is also the state's public procurement manager, concluding and managing statewide contracts on behalf of more than 200 government agencies and 1,600 cooperative procurers. The agency seeks to create a healthy economic environment in Texas by providing a variety of services to business owners, taxpayers, local officials, centers and residents of Texas. The controller's office also manages a variety of programs, including the State Department of Energy, Texas College's savings plans, state-wide procurement initiatives, and more.

Based on more than a century of experience in managing state finances and the culture of public accountability to the public, the Comptroller's Office adheres to a policy of maximum transparency to cover information on the formation and use of the state budget, local commitments, a special section has been created on the website of the Comptroller's Office called "Transparency".

However, the tab states that understanding how the state government collects and spends "tax" dollars is quite simple and offers various options for visualizing information in an accessible form. The section widely presents information in terms of four blocks:

- $\quad$ first, revenues and expenditures, which in turn contain information on all categories of revenues and expenditures over a long period of time, and it is not just the amount of funds, but information in an accessible form about related funding objects involved by the agency in 


\section{І. О. Школьник, Н. Г. Виговська, Ю. С. Гаврии, А. О. Іванченко}

Транспарентність державних та місцевих фінансів: зарубіжний досвід

providing services with the ability to view for each operation (Fig. 1). The tab also contains clear instructions for obtaining the necessary information. In addition, this section provides information on the costs of economic development. The section also provides information on all concluded contracts. In addition, there is a separate tab on the history of state taxes and fees in Texas, beginning in 1972, which indicates how and when the changes in taxation took place and what caused them. In addition, analytical information is provided in an accessible form in one edition in the form of the State Tax Guide for the current year.
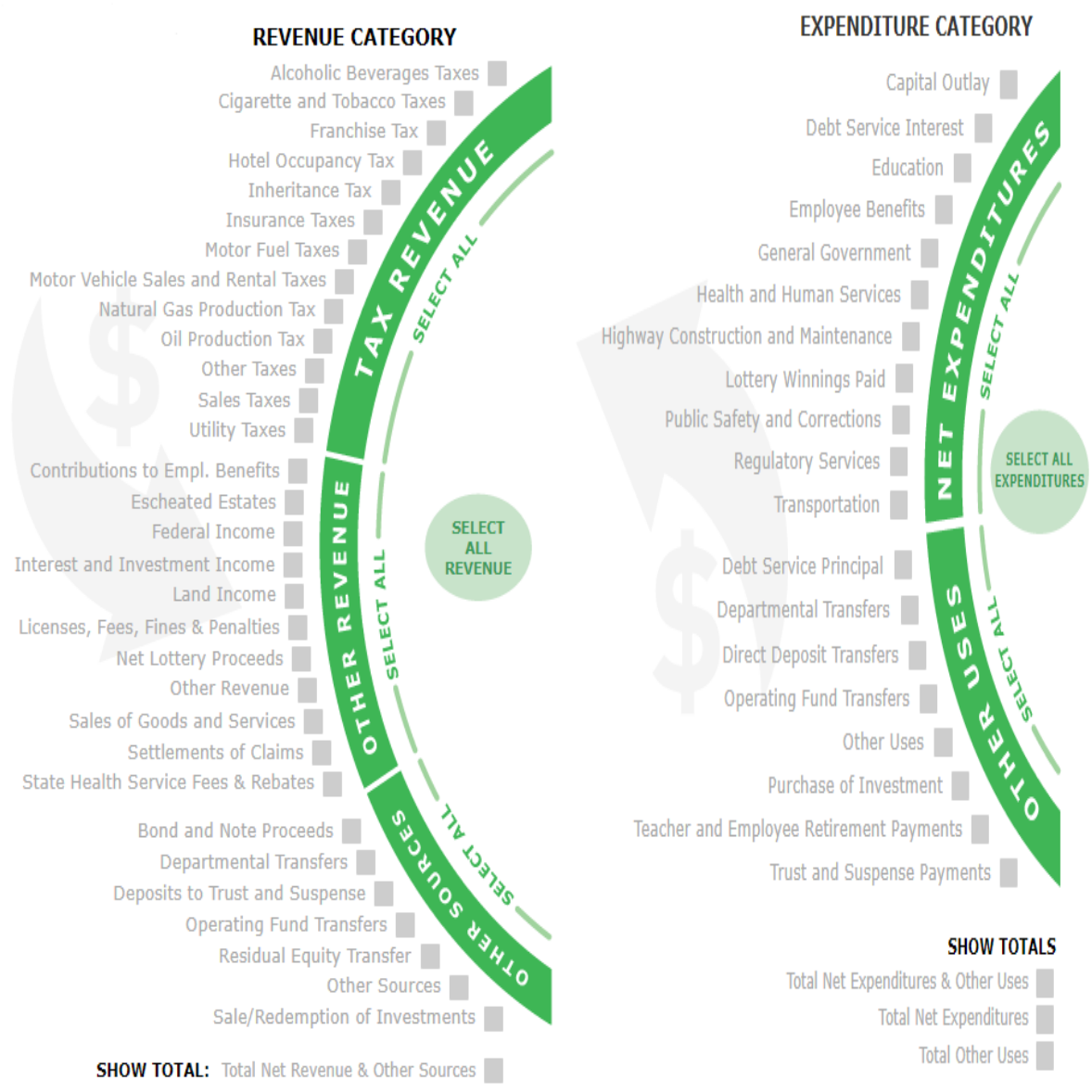

Figure 1. Types of revenues and expenditures according to the Texas Public Accounts Comptroller's Office [21]

- $\quad$ second, budget and finance. This tab presents financial reports and forecasts with a significant list of systematized information in various areas such as financial reports, publications in the context of fiscal management, fiscal notes, information on the activities of the state budget committee); the budget process is fully covered and its significance is explained; information on state investments is covered; a whole section is presented with a 
detailed explanation for citizens on the understanding of the comprehensive annual financial report, which includes the conclusions of the independent audit; in addition, a report on the movement of state money is presented. Every two years, a revenue forecast for the next 2 years is published, which presents an analysis of the current economic situation and a further plan for the financial condition of Texas.

- $\quad$ third, a block that provides open information and open data with detailed analysis and explanations for all settlements in the state; information on state debt, the reasons for its occurrence, maintenance costs, etc.; information on state and local pension funds is presented here, with detailed information on each pension plan; convenient access to search of necessary data in the context of types of economic activity is also presented separately.

- fourth. The transparency tab also contains a block of information on the status of all local finances, accompanied by the text "See how local governments stepping up through Texas to give taxpayers like you a clear view of where your money is going. Who has an online budget? Who shows the detailed costs? Who sets the standard? We monitor how transparent cities, counties, school districts and other special state districts use your hardearned dollars.” [21].

Comparing the website of the Texas Comptroller's Office with the results of a study of Ukrainian websites on the transparency of public authorities, it is possible say that the main advantage of the Comptroller's Office is that all budget and financial information is accumulated on one information resource, which has been specially developed a section that is designed to improve the transparency of government to the public. Thus, when researching the websites of the Ukrainian authorities, the search for the necessary information takes a relatively longer time. In addition, the built-in toolkit "State Revenue and Expenditure Panel" introduced in 2011 has a significant array of statistics and is on the portal of the Office of the Comptroller, a similar toolkit was created in 2018 in Ukraine - the so-called "Openbudget”, a separate site where budget information is presented in the form of tables and diagrams, but the limitation of two years does not allow for effective analysis taking into account previous periods [18].

According to the International Budget Partnership and its study of the openness of the state budget of 117 countries, New Zealand is the most open to the public in terms of budget transparency. A study of the New Zealand Treasury website can help to draw some conclusions about improving the level of openness of Ukrainian resources [22].

A study of the web portal revealed that the Treasury presents a preliminary budget plan, which reveals the broad parameters of fiscal policy in the run-up to the executive's budget proposal; describes the government's economic forecast, expected revenues, expenditures and debt.

The draft executive budget is submitted by the executive to the legislature for approval, which details the sources of revenue, the distribution of funds to ministries, proposed policy changes, and other information important for understanding the fiscal situation in the country.

The site presents both the current budget and previous budgets since 1997. A separate page has been created for each budget on the website, which in addition to the budget itself presents various reports on specific budgets by public authorities, description of fiscal strategy, budget execution forecasts and semi-annual performance reports, budget estimates and specific reports on capital investments, household income, etc. The semi-annual budget review published on the website includes a comprehensive update of the budget execution as of the middle of the financial year; includes a review of economic assumptions and an updated forecast of budget results. 
The Treasury website also provides a link to the specially created website for the current year's budget "Budget2020", which accumulates all the information related to the implementation, development, implementation and supplementation of the budget.

South Africa is another country that is among the top leaders in budget transparency, so we similarly chose the website of the Treasury of South Africa as the main portal of budget information for comparison with Ukrainian resources [17].

The study of the site revealed that it is a single portal with all financial information on the budget, both at the state and local levels and contains information from the Ministry of Finance, data on tenders, suppliers, legislation and bills, etc.

Regarding budget information, on the site we can see statistics from state and local budgets from 1993 to 2020. A separate folder has been created for each year, containing all the main points of the budget, budget statistics, as well as performance reports, budget estimates and specific reports on capital investments, household income, etc. The Local Budgets tab contains a budget guide, local allocations, estimates of local revenues and expenditures, and standardized spreadsheets in Excel format.

Additionally, the Treasury website has a link to a special portal for visualization, study and download of the data. You can see on it in an accessible form the composition of state and local budgets, where and in what proportion are government expenditures, where do revenues come from, and so on. Following the link, each area can be explored in more detail. This portal is an analogue of the Ukrainian OpenBudget, but with more detailed information.

To compare the budget portals of the considered countries with Ukraine, we conducted a study of the main information channels on the state of transparency of government bodies, such as the Ministry of Finance, the State Treasury Service and the State Fiscal Service of Ukraine. The latter did not provide any statistical information on the implementation of budgets and their content, so this portal is not considered. The websites of the Ministry of Finance and the State Treasury Service of Ukraine are filled with almost similar information. The website of the Ministry of Finance presents such information as the draft budget for the next year, the current budget and previous budgets, i.e. more planned information related to the formation and planning of the budget.

The Treasury website provides more up-to-date information on budget execution with a detailed list of all indicators. The website of the Ministry of Finance also contains information on the implementation of local budget revenues, which is updated monthly, but is presented in a text format that is inefficient and requires a lot of time to process. The Treasury website additionally contains monthly reports on the execution of the state budget by revenues and revenues to local budgets. This information is presented in terms of regions, but without specifying the managers of funds.

During the research of the website of the Ministry of Finance of Ukraine, a link to the OpenBudget portal was found, which provides all possible information on the implementation of both state and local budgets for 2018 and 2019. The information is presented in the form of diagrams and tables with explanations. With regard to local budgets, a full budget is provided for each fund manager, as well as in terms of the main items of revenue - tax, non-tax, income from capital transactions and official transfers. Expenditures by functional classification are also presented. This portal can be used as the main information base for the analysis of state and local budgets and indicators of their implementation. The disadvantage of OpenBudget is that it works only 2 years and does not contain information about previous years.

So, in fact, Ukrainian portals provide similar information on budget openness, but the level of content and quality of data is at different levels, as the reports presented on New Zealand 
sites fully reflect the actual picture of budget policy. At the same time, the websites of Ukrainian public authorities do not contain text reports that explain the reasons for deviations from the planned indicators in a form accessible to the population. In addition, data on the state of both consolidated, state and local budgets available for the period from 2007 to the current 2020 are given in three values approved by the Verkhovna Rada for the year, and they are indicated with changes that were then made, a separate target considering the changes and the fact of implementation. The changes themselves in an accessible form have no comments. In addition, the results of audits conducted by the Accounting Chamber of Ukraine are very difficult for non-specialists, and they are quite difficult to draw conclusions about the effectiveness of public finances in Ukraine.

Conclusions. According to the results of the study, it can be argued that the openness of the budget process of public authorities of Ukraine annually undergoes qualitative changes and gradually, following global trends, becomes more accessible to the public from the perspective of accountability, i.e. the disclosure of budget activities representatives of the public to participate in the formation of state budget policy and indirect control over its implementation.

On the other hand, if we compare the transparency of the Ukrainian government with world leaders in this matter, a list of controversial issues arises. First of all, the level of openness of state authorities is influenced by the system of institutions of power in the state and their status. Thus, the main leaders in the field of transparency are states that have a significant history of development and formation of democratic institutions and independent branches of government. In such states, the institution of the public is developed, which creates a demand for openness of power, and in case of misuse of budgetary resources, government officials will be removed from their powers. In such an environment, the authorities try to act as much as possible in the legal sphere and with maximum openness, which creates trust on the part of citizens. In Ukraine, the institution of citizenship is at the stage of formation and development, and state institutions do not have full independence and fullness of power, as well as public support, in which case government officials hide their wrongdoing by not providing full and accessible reporting on the budget process which creates a certain information vacuum for the formation of public protests in order to eliminate corrupt officials.

References

1. Bak, N.A. (2017). Prozorist biudzhetnoho protsesu yak faktor pidvyshchennia efektyvnosti biudzhetnoho menedzhmentu $\mathrm{v}$ Ukraini. [Transparency of the budget process as a factor of the budget management efficiency' rising in Ukraine]. Naukovyi visnyk Chernivetskoho natsionalnoho universytetu imeni Yuriia Fedkovycha. Seriia Ekonomika. Retrieved from: http://econom.chnu.edu.ua/wp-content/uploads/2017/02/statya-Bak.pdf. [in Ukrainian].

2. Vinnichenko, N.V. (2018). Transformation of budget management in conditions of reforming the public finance sector in Ukraine. Doctor's thesis. Sumy: Sumy State University [in Ukrainian].

3. Gasanov, S. S. (2017). Pidvyshchennia rivnia transparentnosti ta funktsionalnosti derzhavnykh finansiv $v$ umovakh strukturnykh reform. [Increasing the transparency level and functionality of public finance under structural reforms]. Finansy Ukrainy, 8, 7-32. [in Ukrainian].

4. Lavrentiev, M. M. (2018). Suchasnyi instrumentarii rozvytku rehioniv: instytutsiini zminy. [Modern Toolkit for Regional Development: Institutional Change]. Mekhanizm rehuliuvannia ekonomiky, 2, 45-58. https://doi.org/10.21272/mer.2018.80.04. [in Ukrainian].

5. Nakonechna, Yu., Demydenko, L. (2016). Vidkrytist ta prozorist derzhavnoho ta mistsevykh biudzhetiv v Ukraini. [Opennes and transparency of state and local budgets in Ukraine]. Visnyk 
І. О. Школьник, Н. Г. Виговська, Ю. С. Гаврии, А. О. Іванченко

Транспарентність державних та місцевих фінансів: зарубіжний досвід

Kyivskoho natsionalnoho universytetu imeni Tarasa Shevchenka. Ekonomika. 10 (187), 20-27. [in Ukrainian].

6. Tereshchuk, H. (2019). Zarubizhna praktyka zabezpechennia pryntsypu transparentnosti v diialnosti publichnoi administratsii. [Foreign practice providing of the transparency principle in public administration activities]. Aktualni problemy pravoznavstva, 3 (19), 65-70. [in Ukrainian].

7. Tereshchuk, H. (2018). Realizatsiia pryntsypu transparentnosti v roboti orhaniv mistsevoho samovriaduvannia. [Implementation of the principle of transparency in the practice of local governments]. Pidpryiemnytstvo, hospodarstvo i pravo, 2018. 5, 141-145. [in Ukrainian].

8. Birskyte, L. (2019). Determinants of budget transparency in lithuanian municipalities. Public Performance and Management Review, 42(3), 707-731. doi:10.1080/15309576.2018.1507915

9. de Renzio P., Wehner, J. (2017). The impacts of fiscal openness. World Bank Research Observer, 32(2), 185-210. doi:10.1093/wbro/lkx004

10. De Simone, E., Bonasia, M., Gaeta, G. L., \& Cicatiello, L. (2019). The effect of fiscal transparency on government spending efficiency. Journal of Economic Studies, 46(7), 1365-1379. doi:10.1108/JES-03-2019-0123

11. Erjavec, N., Jakšić, S., \& Mačkić, V. (2017). What determines the fiscal success at a local level? the case of croatian local government units. Croatian Operational Research Review, 8(1), 283-297. doi:10.17535/crorr.2017.0018

12. Ganapati, S., Cid, G. P., \& Reddick, C. G. (2019). Online fiscal transparency of US state governments: An analysis using public value framework doi:10.1007/978-3-030-14446-3_3 Retrieved from www.scopus.com

13. Hartog, M., \& Bakker, K. (2018). Participatory budgeting in public administrations: Barriers and opportunities for a transparent government. Paper presented at the Proceedings of the European Conference on e-Government, ECEG, , 2018-October 317-320. Retrieved from www.scopus.com

14. International Monetary Fund. (2014). The Fiscal Transparency Code. Retrieved from: https://www.imf.org/en/Publications/Policy-Papers/Issues/2016/12/31/Update-on-the-FiscalTransparency-Initiative-PP4888

15. International Monetary Fund. (2019). The Fiscal Transparency Code. Retrieved from: https://www.imf.org/external/np/fad/trans/Code2019.pdf

16. Liuta, O. \& Mershchii, B. (2019). Assessment of the social and economic development of a region: essence, methodology and correlation with transparency of local authorities. Public and Municipal Finance, 8(1), 83-93. doi:10.21511/pmf.08(1).2019.07

17. National Treasury Republic of South Africa. URL: $\mathrm{http} / /$ www.treasury.gov.za/documents/national\%20budget/default.aspx (дата звернення: 20.09.2020).

18. Open Budget - Державний веб-портал бюджету для громадян. URL: https://openbudget.gov.ua/ (дата звернення: 18.09.2020)

19. Ríos, A. -., Guillamón, M. -., Benito, B., \& Bastida, F. (2018). The influence of transparency on budget forecast deviations in municipal governments. Journal of Forecasting, 37(4), 457-474. doi:10.1002/for.2513

20. Shkolnyk I., Melnik T., Havrysh Y., Ivanchenko A. Transparency of local finances of Ukraine. Public and Municipal Finance. 2019. Vol. 8. Issue 1. P. 73-82.

21. Texas Financial Controller Service. URL: https://comptroller.texas.gov/transparency/ (дата звернення: 15.09.2020)

22. The Treasury of New Zealand. URL: https://www.treasury.govt.nz/publications/budgets/budget-2020 (дата звернення: 19.09.2020)

23. Zepic, R., Dapp, M., \& Krcmar, H. (2017). Reasons for low participation in german participatory budgeting: A public administration perspective. Paper presented at the Proceedings of the European Conference on e-Government, ECEG, , Part F129463 262-269. Retrieved from www.scopus.com

Manuscript received 27.06.2020 
Inna O. Shkolnyk, Nataliia G. Vyhovska, Yuliia S. Havrysh, Andrii O. Ivanchenko Transparency of Public and Local Finances: Foreign Experience

Транспарентность государственных и местных финансов: зарубежный опыт

\author{
ИННА АЛЕКСАНДРОВНА ШКОЛЬНИК*, \\ НАТАЛЬЯ ГЕОРГИЕВНА ВЫГОВСКАЯ ${ }^{* *}$, \\ ЮЛИЯ СТАНИСЛАВОВНА ГАВРЫШ ${ }^{* * *}$, \\ АНДРЕЙ АЛЕКСАНДРОВИЧ ИВАНЧЕНКО ${ }^{* * * *}$ \\ * доктор экономических наук, профессор, заведующая кафедрой финансов, банковского дела и \\ страхования Сумского государственного университета, \\ ул. Петропавловская, 57, г. Сумы, 40000, Украина, \\ тел.: 00-380-50-9179473, e-mail: y.shkolnyk@uabs.sumdu.edu.ua \\ ** доктор экономических наук, профессор, заведующая кафедрой финансов и кредита \\ Государственного университета «Житомирская политехника», \\ ул. Чудновская, 103, г. Житомир, 10005, Украина, \\ тел.: 00-380-68-1709250,e-mail:vygng@ukr.net \\ **** магистрантка Учебно-научный институт бизнес-технологий "УАБС" \\ Сумского государственного университета, \\ ул. Петропавловская, 57, г. Сумы, 40000, Украина, \\ тел.: 00-380-542-665110, e-mail: juliagavrish0407@gmail.com \\ ***** магистрант, Учебно-научный институт бизнес-технологий "УАБС" \\ Сумского государственного университета, \\ ул. Петропавловская, 57, г. Сумы, 40000, Украина, \\ тел.: 00-380-542-665110, e-mail: lantiec.andrey@gmail.com
}

В современных условиях существенно возрастает роль транспарентности как государственных, так и местных финансов, которая является инструментом повышения эффективности использования финансовых ресурсов, что подтверждает проведенный анализ украинских и зарубежных исследований. В Украине с каждым годом уровень транспарентности улучшается и по состоянию на 2019 оценен международными организациями как минимально допустимый. При этом уровень транспарентности местных бюджетов существенно отличается в разных регионах. Для улучшения ситуации и имплементации лучших практик в сфере транспарентности публичных финансов как на государственном, так и на местном уровнях важное значение приобретает анализ зарубежного опыта тех стран, которые являются лидерами в рейтингах транспарентности публичной власти и прозрачности бюджетного процесса, что и было целью данного исследования. В работе проанализирован опыт Офиса Техасского контроллера государственных счетов (США), Казначейства Новой Зеландии и Казначейства Южной африканской республики, которые, согласно рейтингу открытости государственного бюджета, предоставленного Международным бюджетным партнерством, входят в 10 самых прозрачных стран. Анализ содержания информационного портала офиса Техасского контроллера государственных счетов показал наличие отдельного раздела Транспарентность с подробным представлением информации в разрезе ключевым блоков по доходам и расходам, по бюджету и финансам штата, информации по формированию и использованию средств во всех населенных пунктах штата, информации о состоянии дефицита бюджета, а также информации о прозрачности на уровне отдельных населенных пунктов, школьных округов и тому подобное. Сделан сравнительный анализ с состоянием транспарентности украинских государственных органов, отвечающих за разработку и реализацию финансовой политики и определены слабые и сильные стороны в части их транспарентности. Установлено, что открытость процесса использования публичных финансов в Украине постепенно растет, при этом улучшаются и позиции в мировом рейтинге транспарентности. Концептуальное отличие между построением сайтов проанализированных стран и Украины заключается в том, что они отчитываются перед 
і видаткам, по бюджету та фінансам штату, інформація по формуванню та використанню коштів у всіх населених пунктах штату, інформація щодо стану дефіциту бюджету а також інформацію про прозорість на рівні окремих населених пунктів, шкільних округів, тощо. Зроблено порівняльний аналіз із станом транспарентності українських державних органів, що відповідають за розробку та реалізацію фінансової політики та визначено слабкі і сильні сторони в частині їх транспарентності. Встановлено, що відкритість процесу використання публічних фінансів в Україні поступово зростає, при цьому покращуються і позиції в світовому рейтингу транспарентності. Але при цьому концептуальна відмінність між побудовою сайтів проаналізованих країн полягає в тому, що вони звітують перед платниками податків в доступній їм формі, а не просто висвітлюють наявну інформацію без коментарів та роз'яснень.

Ключові слова: відкритий бюджет, партисипація, публічні фінанси, рейтинг, фіскальна політика.

JEL Code: H11, H61

Figures: 1; References: 23

Language of the article: English

Лimepamypa

1. Бак Н.А. Прозорість бюджетного процесу як фактор підвищення ефективності бюджетного менеджменту в Україні. Науковий вісник Чернівещького наиіонального університету імені Юрія Федьковича. Серія Економіка. 2017. №2. URL: http://econom.chnu.edu.ua/wpcontent/uploads/2017/02/statya-Bak.pdf (дата звернення 01.08.2020).

2. Винниченко Н. В. Трансформація бюджетного менеджменту в умовах реформування сектору публічних фінансів в Україні : дис. ... д-ра екон. наук : 08.00.08 / СумДУ, Суми, 2018. 471 с.

3. Гасанов С. С. Підвищення рівня транспарентності та функціональності державних фінансів в умовах структурних реформ. Фінанси Украӥни. 2017. № 8. С. 7-32.

4. Лаврентьєв М. М. Сучасний інструментарій розвитку регіонів: інституційні зміни. Механізм регулювання економіки. 2018. 2. C. 45-58. https://doi.org/10.21272/mer.2018.80.04.

5. Наконечна Ю., Демиденко Л. Відкритість та прозорість державного та місцевих бюджетів в Україні. Вісник Київсккого начіонального університету імені Тараса Шевченка. Економіка. 2016. № 10 (187). С. 20-27.

6. Терещук Г. Зарубіжна практика забезпечення принципу транспарентності в діяльності публічної адміністрації. Актуальні проблеми правознавства. 2019. № 3(19). С. 65-70.

7. Терещук Г. Реалізація принципу транспарентності в роботі органів місцевого самоврядування Підприємництво, господарство і право. 2018. № 5. С. 141-145.

8. Birskyte L. Determinants of budget transparency in Lithuanian municipalities. Public Performance and Management Review. 2019. Vol. 42, № 3. P. 707-731. doi:10.1080/15309576.2018.1507915.

9. de Renzio P., Wehner J. The impacts of fiscal openness. World Bank Research Observer. 2017. Vol. 32, № 2, P. 185-210. doi:10.1093/wbro/lkx004.

10. De Simone E., Bonasia M., Gaeta G. L., Cicatiello L. The effect of fiscal transparency on government spending efficiency. Journal of Economic Studies. 2019. Vol. 46. № 7. P. 1365-1379. doi:10.1108/JES-03-2019-0123.

11. Erjavec N., Jakšić S., Mačkić V. What determines the fiscal success at a local level? the case of Croatian local government units. Croatian Operational Research Review. 2017. Vol. 8 № 1. P. 283297. doi:10.17535/crorr.2017.0018.

12. Ganapati S., Cid G. P., Reddick C. G. (). Online fiscal transparency of US state governments: An analysis using public value framework. 2019. doi:10.1007/978-3-030-14446-3_3 URL: www.scopus.com.

13. Hartog M., Bakker K. Participatory budgeting in public administrations: Barriers and opportunities for a transparent government. Paper presented at the Proceedings of the European Conference on $e$ Government, ECEG. 2018. October. P. 317-320. 


\section{І. О. Школьник, Н. Г. Виговська, Ю. С. Гавриш, А. О. Іванченко}

Транспарентність державних та місцевих фінансів: зарубіжний досвід

14. International Monetary Fund. The Fiscal Transparency Code. 2014. URL: https://www.imf.org/en/Publications/Policy-Papers/Issues/2016/12/31/Update-on-the-FiscalTransparency-Initiative-PP4888.

15. International Monetary Fund. The Fiscal Transparency Code. 2019. URL: https://www.imf.org/external/np/fad/trans/Code2019.pdf.

16. Liuta O. Mershchii B. Assessment of the social and economic development of a region: essence, methodology and correlation with transparency of local authorities. Public and Municipal Finance. 2019. Vol. 8 № 1. P. 83-93. doi:10.21511/pmf.08(1).2019.07.

17. National Treasury Republic of South Africa. http://www.treasury.gov.za/documents/national\%20budget/default.aspx (дата звернення: 20.09.2020).

18. Open Budget - Державний веб-портал бюджету для громадян. URL: https://openbudget.gov.ua/ (дата звернення: 18.09.2020).

19. Ríos A., Guillamón M., Benito B., Bastida F. The influence of transparency on budget forecast deviations in municipal governments. Journal of Forecasting. 2018. Vol. 37. № 4. P. 457-474. doi:10.1002/for.2513.

20. Shkolnyk I., Melnik T., Havrysh Y., Ivanchenko A. Transparency of local finances of Ukraine. Public and Municipal Finance. 2019. Vol. 8. Issue 1. P. 73-82.

21. Texas Financial Controller Service. URL: https://comptroller.Texas.gov/transparency/ (дата звернення: 15.09.2020).

22. The Treasury of New Zealand. URL: https://www.treasury.govt.nz/publications/budgets/budget-2020 (дата звернення: 19.09.2020).

23. Zepic R., Dapp M., Krcmar H. Reasons for low participation in German participatory budgeting: A public administration perspective. Paper presented at the Proceedings of the European Conference on e-Government, ECEG, Part F1294632017 P. 262-269. 